\title{
Some aspects of seasonal dynamics of ground beetles in the agrarian landscapes of Kuban Region (Coleoptera, Carabidae)
}

\author{
Alexandr S. Zamotajlov*, Eugeniy E. Khomitskiy, and Alexandr I. Belyi \\ I.T. Trubilin Kuban State Agrarian University, Kalinina 13, 350044 Krasnodar, Russia
}

\begin{abstract}
The paper discusses influence of some elements of the organic farming and organic fertilizers on carabids dynamics in the foothill zone of the Krasnodar Territory. Species realizing their life cycles in the greenhouses conditions are also identified. Structure of the winter fauna during the warm periods of winter as well as during the snowy and frosty periods is revealed.
\end{abstract}

\section{Introduction}

The list of ground beetles of agricultural landscapes (arable lands, gardens, and forest strips) of the Northwest Caucasus totals according to our data about 350 species. Carabid beetles are mainly polyphagous and their feeding behaviour ranges from complete zoophagy to complete phytophagy, however most carabids in the agroecosystems are facultatively predaceous insects. They are known to be predators of a wide range of invertebrates, including pests of different crops. Most of the ground beetles in temperate climate are herpetobionts, but there are also species inhabiting grassy or woody vegetation, and it is known, that several large-sized beetles of the genus Carabus climb and hunt on plants and even on the walls of buildings [1]. Such adaptations provide carabids an opportunity to control effectively various pests in the soil, on the soil surface, and on the shoots of plants. At the same time, the primitive digestive system of carabids makes them extremely voracious predators of all mesofauna. Carabids occur in a wide range of habitats and are important elements of agroecosystems. This fact causes an interest to ground beetles as potential agents of biological control. Intensive studies of ground beetles in agrocoenoses of the Northwest Caucasus started in the 1970s, and have continued until now. This study focuses on the results of the latest studies of the carabid beetles communities and their dynamics in the foothill zone of the Krasnodar Territory.

\section{Material and methods}

\footnotetext{
*Corresponding author: a_zamotajlov@mail.ru
} 
The present research was carried out in 2012 - 2018 in the foothill zone of the Krasnodar Territory, both in the field and in greenhouses. The material was sampled using pitfall (Barber) traps, each trap was a 0.5 liter plastic glass with a $90 \mathrm{~mm}$ diameter input, filled up to one third with a fixing liquid, either $9 \%$ solution of acetic acid (for taxonomic and dynamics studies) or $4 \%$ formalin (for the anatomic studies), traps were protected from rainfall by plastic covers pinned $2 \mathrm{~cm}$ above the ground. A series of 10 traps was placed at intervals of 4-10 m on experimental plots. The material was sampled every decade. In some experiments, the "sector" traps were used to study surrounding biotopes - sources of migrants. Some carabids were also collected manually. The physiological state of adult carabids was determined according to Wallin [2], with some modifications [3]. Life cycles and demographic structure were described using the conventional terminology [4].

\section{Results and discussion}

Studies carried out in the foothill zone of the Krasnodar Territory in 2013 at two neighboring experimental agrarian sites, first treated according to the organic farming principles, and the second, not affected by agricultural treatment for 10 years, revealed significant difference in their species composition. Both species sets possess nearly the same composition of ecological groups, differences are observed in the abundance of species in each one. The maximum abundance of species of each ecological group was observed at the first plot. This is caused probably by forming preferable temperature and humidity conditions, thus organic farming techniques render a positive effect on the increase of species abundance of the predominant zonal ecological groups in comparison with the untreated plot. Both plots possess also nearly the same range of the adult life forms, difference affects species abundance of each one, being also higher at the first plot. It is possible to conclude, that introduction of the elements of organic farming in the foothills of the Krasnodar Territory attracts ground beetles and creates favorable conditions for realization of their life cycles, against the backdrop of an abandoned site. A separate study on the effect of organic fertilizers on ground beetles was also conducted at the same region. The experiment lasted from June 1 to September 1, 2015. As a result, 34 species were collected at the plot with application of organic fertilizers, and only 19 species at the plot without organic fertilizers, i.e. 1.7 times less. Almost identical trend was noted comparing the number of ground beetles individuals collected during the entire period of observations at the experimental sites, at the plot with application of organic fertilizers it exceeded the plot without organic fertilizers by 2.6 times. Analysis of the ecological groups' composition of each site manifests only minor differences, though it is also more diverse at the first plot. A higher variety of the adult life forms was also observed there. These results confirm the positive impact of organic fertilizers on both species diversity and the number of carabids.

An attempt was made to ascertain the role of greenhouses as "residential", permanently populated by carabids, biotopes. A studied greenhouse with an area of 24 square meters was located at a homestead in the foothill zone of the Krasnodar Territory. The study was conducted from the third decade of December 2015 to the first decade of August 2016. It was revealed, that greenhouse is an unsuitable station for realization of the life cycle of the most carabids, and is "transit" for the bulk of species. However, two species (Harpalus rufipes Deg. and Pterostichus anthracinus Ill.) successfully develop in the protected conditions, besides beginning of their activity is recorded there earlier than at the surrounding homestead (fig. 1). 

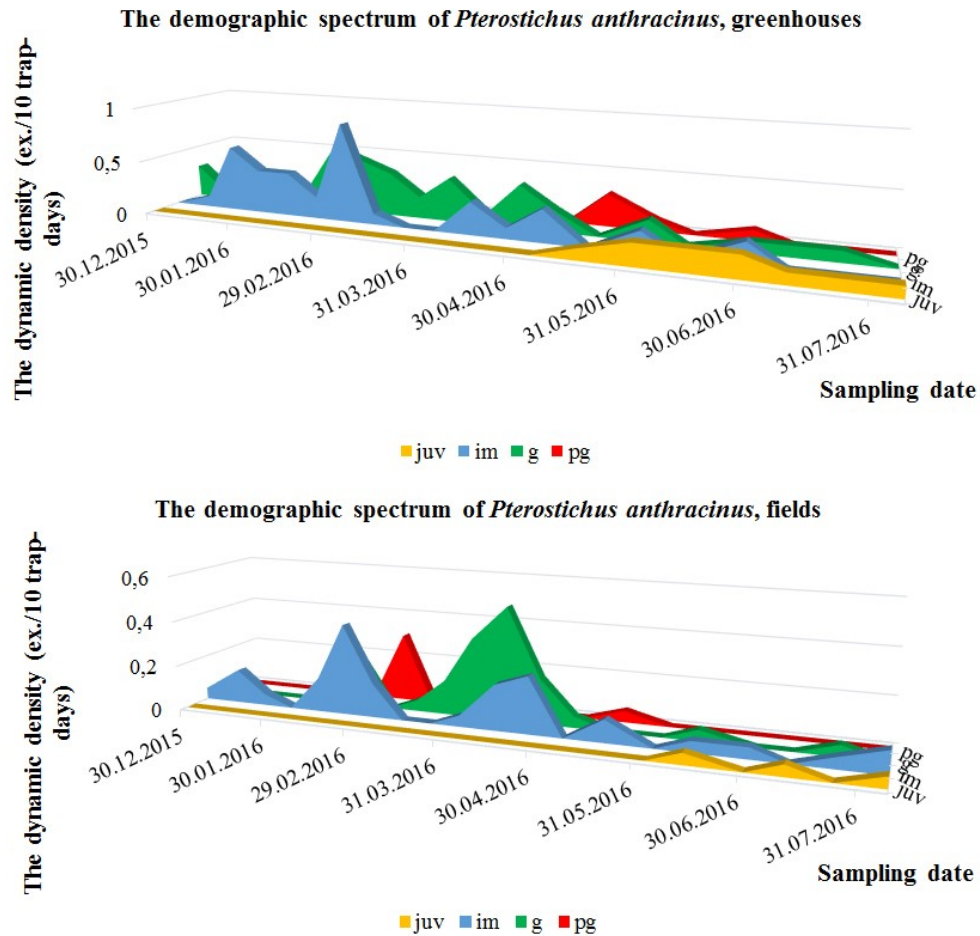

Fig. 1. Dynamics of the ground beetles demographic spectrum in agrocoenoses, Goriachiy Kluch environs, 2015 - 2016. Imaginal stages: juv - juvenile; im - immature; g - generative; pg postgenerative.

Studies of the carabid fauna of this area, formed in winter, were carried out (Table 1). So from January 5 to January 15 , during the warm periods, 15 active ground beetle species were recorded. These species are usually diapausing in winter, and become active only in spring (in early March). But during the research year winter was abnormally warm. Daytime temperatures ranged from $5^{\circ} \mathrm{C}$ to $15^{\circ} \mathrm{C}$, and the night temperatures - from $-20^{\circ} \mathrm{C}$ to $0^{\circ} \mathrm{C}$, with similar temperature values maintained for about 20 days, this apparently led to the insects' overwintering inactivity violation, and the beetles left the wintering shelters much earlier, than normally. It should be noted, that the collected species usually manifest early spring activity, and most of them are capable of migration. The impact of the changing climate on the structural and territorial characteristics of entomofauna has been already noted, but this is the first time, when such serious disturbances of the seasonal dynamics in the forest area at the Northern Macroslope of the Caucasus have been observed. In addition to the activity of the beetles during the warm winter periods, some species are also active during the snowy and frosty winter. This trend was detected in the city of Goriachiy Kluch at the homestead between December 2015 and February 2017. Larvae of Leistus ferrugineus L., Harpalus rufipes Deg., and Nebria brevicollis F. prevailed, the latter species was a superdominant in the larvae structure of dominance (according to Renkonen), for the winter period from December 2015 to February 2016 its share makes 98.9\%, and from December 2016 to February 2017 - 99.1\%. Of the 17 species collected, only 15 had an imago stage, and the dominance structure between December 2015 and February 2016 was following: Acupalpus suturalis Dej. - 18\%, Harpalus distinguendus Duft. - 7.6\%, Nebria brevicollis F. - 24.8\%, Pterostichus anthracinus Ill. $21.9 \%$, and Trechus quadristriatus Schrank. - $20 \%$. Acupalpus suturalis Dej. - $14.3 \%$, 
Nebria brevicollis F. - $20.4 \%$, Pterostichus anthracinus Ill. - $18.4 \%$, and Trechus quadristriatus Schrank. - 34.7 \% dominated between December 2016 and February 2017. Structure of dominance of both larvae and imago during two research years was almost identical, the only difference observed concerns Harpalus distinguendus Duft., in 2016 and 2017 this species was not recorded, this was likely caused by the unfavorable weather conditions.

Table 1. Species composition and quantity of ground beetles, collected in agrocoenoses in winter, Goriachiy Kluch environs, 2015 - 2017.

\begin{tabular}{|c|c|c|c|c|c|c|c|c|c|}
\hline \multirow{4}{*}{ No } & \multirow{4}{*}{ Taxa } & \multicolumn{8}{|c|}{ The life stage } \\
\hline & & \multicolumn{4}{|c|}{ Larva } & \multicolumn{4}{|c|}{ Adult } \\
\hline & & \multicolumn{2}{|c|}{$\begin{array}{l}\text { December, } \\
2015 \text { to } \\
\text { February, } \\
2016\end{array}$} & \multicolumn{2}{|c|}{$\begin{array}{l}\text { December, } \\
2016 \text { to } \\
\text { February, } \\
2017\end{array}$} & \multicolumn{2}{|c|}{$\begin{array}{l}\text { December, } \\
2015 \text { to } \\
\text { February, } \\
2016\end{array}$} & \multicolumn{2}{|c|}{$\begin{array}{c}\text { December, } \\
2016 \text { to } \\
\text { February, } \\
2017\end{array}$} \\
\hline & & $\begin{array}{l}\bigotimes \\
0 \\
\Phi \\
\Phi \\
\Phi \\
0\end{array}$ & 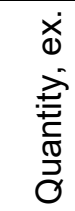 & $\begin{array}{l}\Phi \\
0 \\
\Phi \\
\Phi \\
\Phi \\
\Phi\end{array}$ & 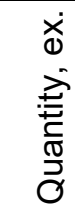 & $\begin{array}{l}\searrow \\
0 \\
\bar{D} \\
\Phi \\
\Phi \\
0\end{array}$ & 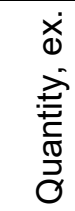 & 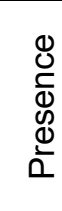 & 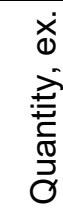 \\
\hline 1 & Nebria brevicollis $F$. & + & 526 & + & 568 & + & 26 & + & 10 \\
\hline 2 & Leistus ferrugineus $L$. & + & 1 & + & 1 & - & - & - & - \\
\hline 3 & Clivina fossor $L$ & - & - & - & - & + & 1 & - & - \\
\hline 4 & $\begin{array}{l}\text { Asaphidion austriacum } \\
\text { Schweig. }\end{array}$ & - & - & - & - & + & 2 & + & 1 \\
\hline 5 & $\begin{array}{l}\text { Bembidion inoptatum } \\
\text { Schaum. }\end{array}$ & - & - & - & - & - & - & + & 1 \\
\hline 6 & $\begin{array}{l}\text { Trechus quadristriatus } \\
\text { Schrank. }\end{array}$ & - & - & - & - & + & 21 & + & 17 \\
\hline 7 & $\begin{array}{l}\text { Paratachys bistriatus } \\
\text { Duft. }\end{array}$ & - & - & - & - & - & - & + & 2 \\
\hline 8 & Poecilus cupreus L. & - & - & - & - & + & 2 & - & - \\
\hline 9 & $\begin{array}{l}\text { Pterostichus } \\
\text { anthracinus III. }\end{array}$ & - & - & - & - & + & 23 & + & 9 \\
\hline 10 & Amara lucida Duft. & - & - & - & - & + & - & + & 1 \\
\hline 11 & Amara tibialis Pk. & - & - & - & - & + & 1 & - & - \\
\hline 12 & $\begin{array}{l}\text { Stenolophus persicus } \\
\text { Mann. }\end{array}$ & - & - & - & - & + & 1 & - & - \\
\hline 13 & $\begin{array}{l}\text { Acupalpus suturalis } \\
\text { Dej. }\end{array}$ & - & - & - & - & + & 19 & + & 7 \\
\hline 14 & $\begin{array}{l}\text { Harpalus distinguendus } \\
\text { Duft. }\end{array}$ & - & - & - & - & + & 8 & - & - \\
\hline 15 & Harpalus rufipes Deg. & + & 5 & + & 4 & - & - & - & - \\
\hline 16 & Harpalus tardus $P z$. & - & - & - & - & + & 1 & - & - \\
\hline 17 & $\begin{array}{l}\text { Microlestes minutulus } \\
\text { Goeze. }\end{array}$ & - & - & - & - & - & - & + & 1 \\
\hline & Total & 3 & 532 & 3 & 573 & 11 & 105 & 9 & 49 \\
\hline
\end{tabular}


The full demographic spectrum of all dominant species collected in winter was observed only in Pterostichus anthracinus Ill., Nebria brevicollis F., and Harpalus rufipes Deg. As a result, this site is "residential" for these species, also it could be permanently inhabited by Harpalus distinguendus Duft., since only juvenile stage is not marked for it, this may be caused by the low activity of the species in question at this stage. Basing on the analysis of the demographic spectrum of the dominant species, Trechus quadriatus Schrank. and Acupalpus suturalis Dej., which is incomplete, this biotope should be defined for them as a "transit". In February 2017, the soil was not covered with snow and the negative temperatures were observed for 7 days (the average temperature for this period was $2.3^{\circ} \mathrm{C}$ ), at this time three Nebria brevicollis F. larvae were collected, this testifies to the negative effect of this phenomenon on activity, on the one hand, and to the ability of larvae of this species to be active even in such adverse conditions, on the other hand. It was also determined that the bulk of the ground beetles imago and larvae are active during the melting of snow and thawed patches formation, as it is evidenced by data obtained from December 2015 to February 2016. Migrations of imago (Trechus quadristriatus Schrank., Acupalpus suturalis Dej., Microlestes minutulus Goeze.) and larvae (Nebria brevicollis F.) under snow during several snowy decades in December 2016 - February 2017 were also recorded. Summarizing the aforesaid, we can conclude, that ground beetles recorded during the research period belong to so called "real winter organisms", conditions preferable for active life of some species in the agrocoenoses of the foothill zone of the Krasnodar Territory are formed even in winter.

The reported study was partly funded by RFBR and the Administration of Krasnodar Territory, project numbers 19-44-230004 and 19-44-233007.

\section{References}

1. E.E. Khomitskiy, A.S. Zamotajlov, A.I. Belyi, Sci. Proc. Stat. Nat. Res. "Prisursky", 33, $3(2018)$

2. H. Wallin, Plant Prot. Rep. Dis. Swedish Univ. Agric. Sci. Uppsala, 15, 17 (1987)

3. A.V. Matalin, K.V. Makarov, ZooKeys, 100, 32 (2011)

4. A.V. Matalin, Zool. Zhurn., 86, 25 (2007) 